\title{
Adolescent work on family farms in Poland - an assessment of hazards
}

\author{
Stanisław Lachowski ${ }^{1, A-F}{ }^{\oplus}$, Bogusława Halina Lachowska ${ }^{2, D-F} \oplus$ \\ ${ }^{1}$ Maria Curie-Sklodowska University, Lublin, Poland \\ ${ }^{2}$ The John Paul II Catholic University of Lublin, Poland \\ A - Research concept and design, B - Collection and/or assembly of data, C - Data analysis and interpretation, \\ $D$ - Writing the article, E-Critical revision of the article, F-Final approval of article
}

Lachowski S, Lachowska BH. Adolescent work on family farms in Poland - assessment of hazards. Ann Agric Environ Med. 2020 ' 27(4): 672-679. doi: 10.26444/aaem/130924

\begin{abstract}
Introduction. Despite dynamic changes in Polish agriculture in the last decades, the participation of children in work in the agricultural sector is still considerable, and an assessment of this phenomenon remains equivocal.

Objective. The aim of the study was presentation of the scale of the engagement of adolescents in work on family farms, and recognition of their opinions concerning risk related with performance of this work, as well as determination of factors related with the assessment of the risk.

Materials and method. The study was conducted in 2016-2017 in a representative group of 511 Polish adolescents aged 14 on a representative group of 5,468 persons within all-Polish studies concerning the economic activity of adolescents, The respondents evaluated work-related risk for their health.

Results.The results of the study showed that approximately $70 \%$ of Polish adolescents from agricultural families help their parents with the performance of work related with running a farm. Adolescents devote about 1 hour during a working day to work on farm. Boys devote to agricultural work more than twice as much time as girls. Risk associated with the performance of agricultural work by adolescents is estimated by the adolescents as low. According to them, work activities in agriculture are rather light, and do not threaten health and safety. Simultaneously, approximately $18 \%$ of adolescents admit that they were involved in an accident at work.
\end{abstract}

Conclusions. In the opinions of the majority of adolescents, work on their parents' farm has rather a positive effect, also on family income, family relations and relations with their contemporaries, as well as education outcomes.

\section{Key words}

adolescents, child work, hazards at work, farming family

\section{INTRODUCTION}

The phenomenon of child work is an important subject of interest in many fields of science, including research dealing with the controversy related with assessment of child work [1] on the effect of work on the children's wellbeing. This is an important problem, considering the scale of this phenomenon. According to statistics of the International Labour Organization (ILO), the phenomenon of child labour substantially decreased worldwide at the beginning of the 21 st century; thus, in 2000, the number of working children aged 5-14 was 211 million (17.6\% of all children at this age) [2], while in 2004, the number of economically-active children at this age decreased by approximately 20 million, and in the following years, a systematic downward tendency was noted to 130 million in 2016 - a decrease by 80.7 million (38.2\%) compared to $2000[3,4]$. However, in the opinions of some researchers, the reports by the ILO and the World Bank pertaining to child labour are deficient, and do not contain data concerning children working without payment for a family business, on a family farm, or in a household $[5,6]$.

Studies conducted to-date have confirmed that poverty is the main reason for children working, as well as traditional practices in a family, lack of sufficient educational

Address for correspondence: Stanisław Lachowski, Maria Curie-Sklodowska University, Plac Marii Curie-Skłodowskiej 5, 20-031, Lublin, Poland E-mail: stlachowski@wp.pl

Received: 22.05.2020; accepted: 26.11.2020; first published: 17.12.2020 opportunities, discontinuation of education, unemployment, employers' demand for cheap labour, family's demand for daily income, lack of sufficient regulations concerning work, and the lack of observance of regulations concerning work. Children work for such economic reasons as interruption of the cycle of poverty in which they live, satisfaction of their basic needs, reduction of a burden on their families, and joint responsibility [7].

In Poland, the data concerning employees under 18 years of age have not been comprehensively reported, and the only available information concerns working adolescents aged under 15, who can be employed based on the regulations specified in the Labour Code [8]. The employment of underage persons on family farms is subject to separate regulations provided in the Act in the Matter of Farmers' Social Insurance [9]. According to this Act, adolescents aged 16 and over, whose parents own a private farm, are fully entitled to social insurance as members of the household.

In many countries, children's work takes place mainly in agriculture [7] which is one of the most dangerous sectors due to work-related fatal accidents, accidents at work other than fatal, and occupational diseases. Approximately 59\% of all children aged 5-17 who perform hazardous work are employed in agriculture $[10,11]$. In addition, work on parents' farm is classified as one of the forms of 'hidden' work, apart from work in the household or in the family business [12]. The investigation of the work of children on a family farm is difficult because it is usually not included 
in the employment statistics. Considering the scale of this phenomenon, it is important to study the effect of this work on children's wellbeing.

The scale of illegal employment of children on the so-called 'grey market' is unknown, neither in Poland nor worldwide, especially in the situation of underage children working on family farms which is not covered by any legal regulations, and not included in statistics. The only source of data are statistics of the Agricultural Social Insurance Fund (KRUS) [13] which were kept until 2004 and concerned children aged under 15 engaged in work on their parents' farm. The first data concerning accident rates among children engaged in agricultural work were published by KRUS in 1993. In that year, farmers reported 430 accidents involving children aged up to 15 [13]. In 1997, the number of reported accident events increased to 1,445 , and remained at a similar level until 2004. Since then, statistics concerning accidents among children have not been kept because the amendment to the Act on the social insurance of farmers [13] abolished the accident claims of children who help with agricultural work. The scale of accidents among children engaged in agricultural work in Poland does not reflect the scale of the phenomenon of child labour; however, it confirms that this is a common phenomenon, and simultaneously indicates that some children are engaged in hazardous work activities which are not adjusted to their capabilities, thus creating actual accident risk and is the cause of these accidents. The majority of the reported cases caused damage to the health of the children, and some have resulted in the death of injured children. During the period from 1999-2003, 26 children lost their lives $[13,14]$.

The Institute of Rural Health in Lublin carried out comprehensive research concerning the phenomenon of the involvement of children working on farms. The studies were conducted in the selected regions of Lublin and Bydgoszcz $[15,16,17]$, and revealed that almost all children aged 11-14 who came from farmers' families were engaged in work on a farm. These children performed various jobs, some of which are considered risky and unsafe, including the operation of tractors and machinery, or associated with tending large animals, and the use of chemical agents [18].

The attention of many researchers dealing with the phenomenon of child work is focused on its negative effects on the wellbeing of these children. Other researchers call for a holistic view of child labour, and postulate not omitting benefits associated with this work, especially with respect to marginalized children $[19,20]$. These researchers indicate that children's work may provide economic benefits, improve the quality of life of the children, and allow coping with poverty. It may also be a source of knowledge supplementing and supporting school education, provide occupational experience and facilitate entering the labour market in the future, bring about psycho-social benefits, especially with respect to improving self-esteem, and help in establishing social relations and shaping responsibility. The results of many studies confirm that the work may be of essential importance for the development of a child and its transition towards the subsequent stages of life [21]. Adolescent work is regarded as positive and approved when it does not negatively affect the development and maturation of the children, nor impinge on their functioning in school $[22,23]$. Nevertheless, the researchers also emphasize the negative aspects of child work, e.g. endangering psychophysical development [22], threatening intellectual development, health, or even life [24].

Based on research carried out in 83 developing countries which included children aged 10-14, a significant positive relationship was found between child labour and mortality among adolescent workers [25]. According to the researchers, the higher mortality among under-age workers is due to the fact that they undertake employment too early, and are engaged in work beyond their capabilities. A negative relationship is also observed between child labour and the state of health of the population. This confirms the assumption that an excessive work load at a young age exerts a negative effect on human health.

Other studies, for example, a study on a group of 1,465 children aged 11-17, from six different countries who worked as domestic helps, showed that the effect of work on children considerably differed: apart from children who worked for too many hours, experiencing physical punishment and exposure to psychosocial damage/injuries, there were children who were able to attend school and benefited from good relationships with employers and support networks [26].

\section{OBJECTIVE}

The aim of the study was presentation of the scale of engagement of adolescents in work on family farms, and recognition of their opinions concerning risk related with the performance of this work, as well as determination of factors related with assessment of the risk.

\section{MATERIALS AND METHOD}

The study was conducted in a representative group of 511 Polish adolescents aged 14-15, living in rural areas, and coming from families running a farm. The study was conducted within an all-Polish study, as part of a grant from the National Science Centre in Kraków entitled 'Psychosocial conditioning of economic activity of junior high school adolescents', and carried out in a representative group of 5,468 persons. The sample was selected by the Laboratory for Social Research (PBS) in Sopot by the method of stratified sampling. The stratified two-stage cluster sampling method was applied, where the strata were provinces and categories of the size of places of residence. The study was conducted in 2016-2016, and covered all provinces in Poland in four size categories: rural area, town with a population up to 20,000 inhabitants, city with a population from 20,000-100,000 inhabitants, and a city with a population of over 100,000. Adolescents who satisfied two criteria simultaneously were selected for analysis within the study: living in a rural area, and coming from an agricultural family. The group of adolescents who met these criteria included 248 girls (48.5\%) and 263 boys (51.5\%). Nearly a half of the respondents were aged 15 (48.3\%), while the remainder were aged 14 (51.7\%).

The study material was collected by means of a questionnaire assessing the adolescents' economic activity, which consisted of eight thematic blocks. The first five of these blocks pertained to the assessment of the size of the phenomenon of the engagement of adolescents in various types of work. In the subsequent block of items, individual types of activity were assessed from seven aspects, three of which concerned health: 
1) self-assessment by adolescents of the heaviness of work activities performed;

2) self-assessment by adolescents of safety while performing work activities;

3) self-assessment by adolescents of the effect of work on health.

The above-mentioned aspects were assessed by the respondents according to a five-degree scale, where ' 1 ' was (respectively): light work, safe work, and work exerting a positive effect on health, whereas ' 5 ' was (respectively): very hard work, very hazardous work, and work exerting a negative effect on health.

The last block concerned the demographic and psychosocial characteristics of the examined adolescents, as well as the socio-demographic characteristics of their families [27].

The results of the study were analyzed by means of statistical software IBM SPSS v.5.1, using stepwise linear regression analysis and Mann-Whitney test.

\section{RESULTS}

The adolescents in the study aged 14-15 come from agricultural families (their parents own a farm, and at least one of them works in agriculture), and, in addition, all live in rural areas. Analysis of the collected material showed that more than $2 / 3$ of adolescents (70.2\%) helped their parents with running the farm, while almost $1 / 3$ of them did not undertake any activity in this respect (Tab. 1). The results demonstrated that adolescents who help their parents on a farm performed agricultural work systematically. This is evidenced by the percentage of adolescents who performed agricultural work during various periods preceding the study. A similar percentage of adolescents were engaged in agricultural work during the week and the month preceding the study, and were mainly the same persons (60.6\% and $62.5 \%$, respectively). Also, a similar percentage of adolescents in the study performed agricultural work during summer vacations preceding the study (62.5\%). Boys more frequently than girls helped their parents with work on a farm. During the year preceding the study, $4 / 5$ of boys (79.2\%) performed this type of work, whereas in the group of girls this percentage was considerably lower (60.9\%). During the remaining analyzed periods, the proportions of boys and girls engaged in agricultural work were similar. The differences were statistically significant.

The adolescents examined devoted a different number of hours to the performance of agricultural work, from those whose engagement in this work was symbolic - about one hour during the periods analyzed, to those who worked for even 150 hours during a month. Per one adolescent helping on a farm in a week preceding the study, there were approximately five working hours in a week, on average, while in a month -16 hours, and 42.56 hours during summer vacations (Tab. 2). In the period of a week and a month, boys devoted twice as much time to work than girls, and during summer holidays - more than twice as much (boys - 59.5 hours; girls - 24.5 hours).

The examined adolescents were asked to provide motivation for working on a family farm. From among the motives proposed they could chose maximum of three which were most important for them, and additionally could indicate another motive not mentioned in the cafeteria. While undertaking work on a farm, the examined adolescents most

Table 1. Undertaking work on a family farm

\begin{tabular}{|c|c|c|c|c|c|c|c|}
\hline \multirow{3}{*}{ Period/Significance of difference between groups } & \multirow{3}{*}{$\begin{array}{l}\text { Undertaking } \\
\text { work }\end{array}$} & \multicolumn{4}{|c|}{ Gender } & \multirow{2}{*}{\multicolumn{2}{|c|}{ Total }} \\
\hline & & \multicolumn{2}{|c|}{ Girls } & \multicolumn{2}{|c|}{ Boys } & & \\
\hline & & $\mathrm{N}$ & $\%$ & $\mathrm{~N}$ & $\%$ & $\mathrm{~N}$ & $\%$ \\
\hline \multirow{3}{*}{ in the week preceding the study $/ \mathrm{chi}^{2}=15.231 ; \mathrm{p}<0.001$} & Yes & 109 & 51.2 & 162 & 69.2 & 271 & 60.6 \\
\hline & No & 104 & 48.8 & 72 & 30.8 & 176 & 39.4 \\
\hline & Total & 213 & 100.0 & 234 & 100.0 & 447 & 100.0 \\
\hline \multirow[t]{2}{*}{ in the month preceding the study/ $\mathrm{chi}^{2}=17.294 ; \mathrm{p}<0.001$} & No & 98 & 48.3 & 66 & 28.8 & 164 & 38.0 \\
\hline & Total & 203 & 100.0 & 229 & 100.0 & 432 & 100.0 \\
\hline \multirow{3}{*}{$\begin{array}{l}\text { during summer vacations preceding the study } / \mathrm{chi}^{2}=12.755 \text {; } \\
\mathrm{p}<0.001\end{array}$} & Yes & 115 & 54.0 & 160 & 70.5 & 275 & 62.5 \\
\hline & No & 98 & 46.0 & 67 & 29.5 & 165 & 37.5 \\
\hline & Total & 213 & 100.0 & 227 & 100.0 & 440 & 100.0 \\
\hline \multirow{2}{*}{$\begin{array}{l}\text { in the year preceding the study/ } \\
\mathrm{chi}^{2}=20.207 ; \mathrm{p}<0.001\end{array}$} & No & 97 & 39.1 & 54 & 20.8 & 151 & 29.8 \\
\hline & Total & 248 & 100.0 & 259 & 100.0 & 507 & 100.0 \\
\hline
\end{tabular}

In the compilation, lack of data was omitted concerning the number of working hours

Table 2. Average time devoted to work on a family farm

\begin{tabular}{|c|c|c|c|c|c|c|c|c|c|}
\hline \multirow{2}{*}{ Period preceding the study } & \multicolumn{3}{|c|}{ Girl } & \multicolumn{3}{|c|}{ Boy } & \multicolumn{3}{|c|}{ Total } \\
\hline & M & $\mathrm{N}$ & SD & $M$ & $\mathrm{~N}$ & SD & $M$ & $\mathrm{~N}$ & SD \\
\hline Week & 2.98 & 213 & 5.50 & 6.92 & 234 & 9.61 & 5.04 & 447 & 8.16 \\
\hline Month & 8.83 & 203 & 14.49 & 22.58 & 229 & 32.41 & 16.12 & 432 & 26.48 \\
\hline Vacations & 24.43 & 213 & 48.27 & 59.57 & 227 & 81.49 & 42.56 & 440 & 69.66 \\
\hline
\end{tabular}


often reported that they undertook this work from a sense of duty towards their family. This motive for participation in agricultural work was reported by a half of the respondents (49.6\%) (Tab. 3). The second motive for work was the request for help from parents (43.1\%). A large group of respondents helped with agricultural work because they considered that this activity is conducive to their development. Such motives included: 'I wish to learn something' $-42.8 \%$, 'I wish to be more independent' - $27.5 \%$, 'I wish to check my skills' - $21.5 \%$, 'I want to run such an activity in the future', i.e. preparation for the job $-16.1 \%$. A similar category of motives was because of passion for this type of work: 'I like working' $-35.4 \%$. To some extent, this is pursuing and developing own interests. The material motive for work played a relatively small role, i.e. 'I wish that the family had a higher income', a motive indicated by every fifth respondent.

A similar percentage of boys and girls indicated the majority of motives for work on a farm. The statistical differences observed concerned three motives. Girls more frequently than boys undertook agricultural work because their parents or caregivers asked them for such help $-56.0 \%$ and $33.5 \%$, respectively. Boys more often than girls performed agricultural work because they liked this work $-41.9 \%$ and $26.7 \%$, respectively. In addition, $1 / 4$ of the boys performed agricultural work because they wanted to become farmers in the future $-24.6 \%$, whereas the percentage of girls guided by this motive was nearly six times lower $-4.7 \%$.

The presented study is an attempt to determine how adolescents who help their parents with running a farm, i.e. perform agricultural work, evaluate risk related with work in agriculture. Assessment of risk was considered from three aspects: assessment of the heaviness of the work performed, assessment of the risk for safety, and assessment of the risk for health. More than $4 / 5$ of respondents evaluated this work as light (20.8\%), or rather light (24.8\%). A similar percentage of adolescents reported that the work performed was neither heavy nor light (41.5\%). The remainder (13.5\%) admitted that the work performed was rather heavy or heavy (Tab. 4). The vast majority of adolescents (66.9\%) did not perceive any risk for safety while performing agricultural work, while other respondents mentioned that this risk was rather low (16.6\%). Only $2.8 \%$ of adolescents considered that the risk for safety while working on a farm was rather high or high. According to the majority of adolescents, the work they performed on a farm did not threaten their health (56.7\%), 18.6\% evaluated this risk as rather low, and $22.5 \%$ as mediocre. Only $2.2 \%$ of respondents mentioned that work on a farm created rather a high or high risk for their health.

Boys more often than girls evaluated work on a farm as heavy or rather heavy, and more frequently than girls considered that agricultural work to be dangerous for them. Nevertheless, boys and girls did not differ with respect to their assessment of risk for health related with performance of agricultural work (Tab. 4).

Table 4. Assessment of hazards associated with performance of work on a farm, according to gender.

\begin{tabular}{lcccccc}
\hline & \multicolumn{6}{c}{ Gender } \\
\cline { 2 - 7 } & \multicolumn{2}{c}{ Girl } & \multicolumn{2}{c}{ Boy } & \multicolumn{2}{c}{ Total } \\
\cline { 2 - 7 } & $\mathrm{N}$ & $\%$ & $\mathrm{~N}$ & $\%$ & $\mathrm{~N}$ & $\%$ \\
\hline Assessment of heaviness of work (chi square & $18.140 ;$ & $\mathrm{p}<0.001)$ \\
\hline light & 51 & 21.2 & 52 & 20.4 & 103 & 20.8 \\
\hline rather light & 74 & 30.7 & 46 & 18.0 & 120 & 24.2 \\
\hline neither hard nor light & 96 & 39.8 & 110 & 43.1 & 206 & 41.5 \\
\hline rather hard & 13 & 5.4 & 28 & 11.0 & 41 & 8.3 \\
\hline hard & 7 & 2.9 & 19 & 7.5 & 26 & 5.2 \\
\hline Total & $\mathbf{2 4 1}$ & $\mathbf{1 0 0 . 0}$ & $\mathbf{2 5 5}$ & $\mathbf{1 0 0 . 0}$ & $\mathbf{4 9 6}$ & $\mathbf{1 0 0 . 0}$
\end{tabular}

Assessment of risk for safety (chi square 29.196; $p<0.0001$ )

\begin{tabular}{lcccccc}
\hline lack of hazards & 190 & 77.6 & 141 & 56.4 & 331 & 66.9 \\
\hline rather small & 34 & 13.9 & 48 & 19.2 & 82 & 16.6 \\
\hline mediocre & 17 & 6.9 & 51 & 20.4 & 68 & 13.7 \\
\hline rather high & 3 & 1.2 & 7 & 2.8 & 10 & 2.0 \\
\hline high & 1 & .4 & 3 & 1.2 & 4 & .8 \\
\hline Total & $\mathbf{2 4 5}$ & $\mathbf{1 0 0 . 0}$ & $\mathbf{2 5 0}$ & $\mathbf{1 0 0 . 0}$ & $\mathbf{4 9 5}$ & $\mathbf{1 0 0 . 0}$
\end{tabular}

Assessment of risk for health (insignificant differences)

\begin{tabular}{lcccccc}
\hline lack of risk & 151 & 62.7 & 129 & 51.0 & 280 & 56.7 \\
\hline rather low & 39 & 16.2 & 53 & 20.9 & 92 & 18.6 \\
\hline mediocre & 45 & 18.7 & 66 & 26.1 & 111 & 22.5 \\
\hline rather high & 5 & 2.1 & 4 & 1.6 & 9 & 1.8 \\
\hline high & 1 & .4 & 1 & .4 & 2 & .4 \\
\hline Total & $\mathbf{2 4 1}$ & $\mathbf{1 0 0 . 0}$ & $\mathbf{2 5 3}$ & $\mathbf{1 0 0 . 0}$ & $\mathbf{4 9 4}$ & $\mathbf{1 0 0 . 0}$
\end{tabular}

Table 3. Motives for performing agricultural work, according to gender

\begin{tabular}{|c|c|c|c|c|c|c|}
\hline \multirow[b]{2}{*}{ Motives } & \multicolumn{2}{|c|}{ Girl } & \multicolumn{2}{|c|}{ Boy } & \multicolumn{2}{|c|}{ Total } \\
\hline & $\mathrm{N}$ & $\begin{array}{c}\% \\
n=150\end{array}$ & $\mathrm{~N}$ & $\begin{array}{c}\% \\
n=203\end{array}$ & $\mathrm{~N}$ & $\begin{array}{c}\% \\
n=353\end{array}$ \\
\hline Parents/caregivers asked for help & 84 & 56.0 & 68 & 33.5 & 152 & 43.1 \\
\hline I wish to learn something & 67 & 44.7 & 84 & 41.4 & 151 & 42.8 \\
\hline I want to be more independent & 43 & 28.7 & 54 & 26.6 & 97 & 27.5 \\
\hline I want to check my skills & 36 & 24.0 & 40 & 19.7 & 76 & 21.5 \\
\hline I wish that the family had a higher income & 30 & 20.0 & 40 & 19.7 & 70 & 19.8 \\
\hline I want to run such an activity in the future & 7 & 4.7 & 50 & 24.6 & 57 & 16.1 \\
\hline I want to be more liked, respected & 7 & 4.7 & 15 & 7.4 & 22 & 6.2 \\
\hline Parents/caregivers forced me to work & 6 & 4.0 & 5 & 2.5 & 11 & 3.1 \\
\hline Colleagues encouraged me to work & 2 & 1.3 & 1 & 0.5 & 3 & 0.8 \\
\hline Other reasons & 13 & 8.7 & 20 & 9.9 & 33 & 9.3 \\
\hline
\end{tabular}


The risk was assessed according to a five-point scale, where: 1 was the lack of risk, and 5 - high risk. Ascribing these values enabled calculation of the mean indicator of hazards for individual dimensions of risk and the overall risk indicator, by summing-up the values of the dimensions. While analyzing the mean indicator for individual dimensions, it was found that all the risk dimensions were evaluated as being below the mean value for the scale, i.e. the value of three (Fig 1). This means that hazards related with work in agriculture were evaluated by adolescents as rather low or low. The highest mean value of risk indicator was observed with respect to the heaviness of the work performed (2.49), a considerably lower value with respect to health risk (1.6), while the lowest - with respect to safety (1.42). In all the dimensions analyzed, risk indicators were higher in the group of boys than girls; this means that boys evaluated risk related with performance of agricultural work as higher, compared to girls.

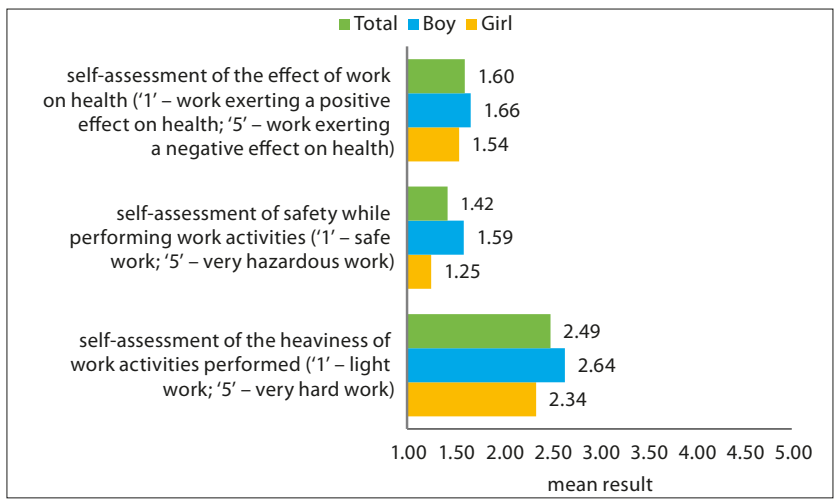

Figure 1. Adolescents' assessment of work-related risk for health and safety, and assessment of heaviness of these work activities, according to gender (mean result)

In order to determine the factors related with the assessment of risk associated with work on a family farm, linear hierarchical regression analysis by the technique of stepwise forward selection was applied. In this model, the dependent variable is a risk indicator, calculated by summingup the evaluation values for three risk dimensions: heaviness of work, risk for safety, and risk for health. The distribution of the variable created in this way, which is a risk indicator, occurred to differ significantly from normal distribution (skewness $=0.689$; curtosis $=0.266$ ). The conversion of raw data by their algorithmization was applied (decimal logarithm). Due to this conversion, a distribution close to normal was obtained.

Independent variables were introduced into the model of linear regression, based on empirical data, representing four blocks:
1) characteristics of the respondent's family (family structure, age, education of the parents, material standard of the family);

2) characteristics of the adolescents (gender, height, weight, self-reported state of health, self-reported physical fitness, and assessment of satisfaction with life);

3) characteristics of work (mean working time in one month, experience of participation in an accident at work);

4) motives for undertaking agricultural work.

According to the requirements of linear regression, nominal variables were converted into dichotomous variables, whereas the ordinal variables were used as the quantitative variables.

The model of conditioning of risk assessment included five predictors: material standard of the family, respondents' gender, assessment of satisfaction with life, experience of involvement in an accident at work, and working time. Material standard of the family was significantly related with evaluation of hazards related with agricultural work: the lower the standard the higher the evaluations of risk reported by adolescents $(\beta=-0.138)$. Higher evaluations of risk while performing agricultural work were mentioned more by boys than girls $(\beta=-0.240)$, as well as those who were less satisfied with life $(B=-0.258)$. The characteristics of the work performed were also predictors of the assessment of hazards: duration of performing work and experience of involvement in an accident at work: the longer the working time the higher the evaluation of the risk $(\beta=0.158)$. The evaluations were also higher when the respondents had experienced involvement in an accident at work $(\beta=0.238)$.

\section{DISCUSSION}

Work in agriculture is characterized by a variety of workplaces, use of complicated and dangerous machinery and tools, use of chemicals, contact with animals, seasonal intensification of work, and performance of work in changeable weather conditions. Due to these characteristics, agriculture is considered one of the most dangerous sectors of the economy. This opinion is confirmed by statistics pertaining to accidents at work, including fatal accidents, and occupational diseases. Risk related with running a family farm concerns not only the farmers themselves, but also their children who help with agricultural work. According to many studies, the engagement of children in work on a farm is commonly observed, and starts at a very early period of life of a child. One of the elements in preventing the negative consequences of adolescent work is the education of children and their parents concerning hazards, and methods for avoiding them.

Table 5. Determinants of assessment of risk to health while performing work on a family farm (hierarchical linear regression).

\begin{tabular}{|c|c|c|c|c|c|c|c|c|}
\hline \multirow{2}{*}{ Block } & \multirow{2}{*}{ Predictor } & \multirow{2}{*}{ B } & \multirow{2}{*}{ SE } & \multirow{2}{*}{$\begin{array}{c}\text { Standardized } \\
\text { coefficients Beta/ß }\end{array}$} & \multirow{2}{*}{$\mathrm{t}$} & \multirow{2}{*}{$\mathrm{p}$} & \multicolumn{2}{|c|}{$95 \% \mathrm{Cl}$ for $\mathrm{B}$} \\
\hline & & & & & & & lower & upper \\
\hline 2) Family characteristics & Assessment of material standard & -0.024 & 0.012 & -0.138 & -2.057 & 0.041 & -0.047 & -0.001 \\
\hline \multirow[t]{2}{*}{ 2) Respondents' characteristics } & Gender & 0.076 & 0.022 & 0.24 & 3.406 & 0.001 & 0.032 & 0.12 \\
\hline & Self-reported satisfaction with life & -0.048 & 0.013 & -0.258 & -3.692 & 0 & -0.073 & -0.022 \\
\hline \multirow[t]{2}{*}{ 5) Scope of participation in work } & Accident at work & 0.084 & 0.024 & 0.238 & 3.492 & 0.001 & 0.037 & 0.132 \\
\hline & Constant & 0.434 & 0.08 & & 5.428 & 0 & 0.276 & 0.592 \\
\hline
\end{tabular}

ANOVA for Regression: $\mathrm{F}=12.002 ; \mathrm{p}<0.001$; explained variability of dependent variable: Adjusted $\mathrm{R}$ Square $=0.239$ 
The problem of child labour is considered one of the leading social problems in all societies worldwide. It is considered that this problem concerns especially the developing or poorlydeveloped/underdeveloped countries [7]. However, in the developed countries, this phenomenon may be overlooked or poorly recognized. Some researchers pay attention to the fact that this problem also concerns developed societies, and indicate the necessity for conducting studies of the phenomenon of child labour in these countries [28], including Poland. In recent years in Europe, the interest in child work has been associated with the belief that despite the lack of alarming data concerning this problem from official statistics, this phenomenon does occur and even develops, especially in the countries affected by economic crisis as well as Central and Eastern Europe [29].

The aim of the study was recognition of the scale of the phenomenon of work on a farm among Polish adolescents aged 14-15, presentation of assessments of hazards related with work, and determination of predictors related with risk assessment. These analyses are a part of research concerning the conditioning of work of adolescents; however, they provide new knowledge by focusing on assessments of hazards by those who are engaged in work, and by seeking factors conditioning these assessments. At the same time, it should be emphasized that the analyses were performed in an all-Polish representative group of adolescents from agricultural families, living in the rural areas.

In this study, attention was focused on child work in agriculture. Investigation of the phenomenon of child work in this sector is very important due to the fact that the majority of working children are engaged in agricultural work; moreover, agriculture is considered one of the most dangerous sectors of economy. Also, children who work in agriculture undertake this work at a relatively young age (younger than in other sectors) and devote a relatively large amount of time to work, especially during certain periods, due to the seasonal character of work in agriculture.

This study presents the characteristics of adolescents engaged in work on their parents' farms, the scope of work performed by them, and their evaluation of hazards related with performance of this work. The respondents were aged $14-15$, i.e. below the age specified as the age above which it is possible to undertake employment [8]. Nevertheless, in this age group the phenomenon of work on a farm is relatively common, and the majority of adolescents were engaged in this work $(70.2 \%$ in the year preceding the study), and it was more prevalent in the group of boys $(79.8 \%)$ than girls $(60.9 \%)$. The data obtained indicate that nearly every third Polish adolescent coming from an agricultural family did not help parents with work on a farm. This result was clearly different from the result of research conducted in the first decade of the 21st century in the Lublin Province, the agricultural region of Eastern Poland () [30].

The studies conducted by the diary method during the period of one year showed that only $2.9 \%$ of farmers' children aged 12-14 did not perform agricultural work. The differences between the presented results may indicate two tendencies observed by researchers dealing with child work. The first tendency concerns the systematic decrease in the indicator of employment of children, including engagement of children in agricultural work, as indicated by ILO statistics? [31]. The second explanation of discrepancies in the assessments of the scale of the phenomenon of work of adolescents on their parents' farms, is provided by regional differences in the economic activity of Polish adolescents. Studies of this problem conducted during 2016-2017, showed that the percentage of adolescents performing work on behalf of a family business was more than twice as high in eastern than western regions of Poland [30].

Adolescents devoted a relatively large amount of time to work, and boys worked considerably more than girls. Apart from this, the amount of time devoted to work was related to the phenomenon of the seasonal character of work in agriculture, which means that adolescents worked more during the summer vacations than during the school year: on a monthly scale, in the group of boys, this was 22.58 hours, on average, during the school year, and 29.78 hours during summer vacations, while in the group of girls -8.83 hours and 12.22 hours, respectively.

Despite the fact that adolescents work in agriculture to a relatively large extent, performing many dangerous jobs without specialist training and frequently without supervision by their parents or other older persons, to a small degree they realize the risk related with the work they perform [18]). The majority of adolescents engaged in work in agriculture did not perceive a risk for their safety (66.9\%) and health (56.7\%) associated with the work performed, and girls did not recognize these hazards more often than boys $(77.6 \%$ and $56.4 \%$, respectively, with respect of risk for safety, and $62.7 \%$ and $51.0 \%$ in the case of risk for health). A low percentage of working adolescents recognized any risk for safety (16.5\%), and for health $(24.7 \%)$ related with their work in agriculture, and usually evaluated this risk as not very high or mediocre. Boys recognized more hazards than girls - risk for safety: $24.4 \%$ and $8.5 \%$, respectively, and in the case of risk for health $-28.01 \%$ and $21.2 \%$. Greater awareness of hazards in the group of working boys compared to working girls, may be associated with the fact that they devoted a larger amount of time to the performance of jobs which they more frequently evaluated as heavy or rather heavy $-18.5 \%$ of boys and $8.3 \%$ of girls evaluated their work as heavy or rather heavy, while more often as light or rather light $-38.4 \%$ and $51.9 \%$, respectively. However, among working adolescents, the awareness of risk related with work in agriculture, considered one of the most dangerous sectors of the economy, is relatively low because it is recognized by about $1 / 4$ of the boys and even less by girls, who rather perceived risk for their own health, while to a considerably lower degree - risk for their own safety.

In order to determine factors explaining the assessment of risk performed by adolescents (approached globally and comprehensively), a multivariate linear hierarchical regression analysis was performed, in which, among the predictors, a wide spectrum of characteristics were considered concerning the adolescent's family, adolescent's work performed, and motivation for undertaking the work. This allowed a simultaneous consideration of a wide range of conditionings, and an indication of factors which are of great importance in the explanation of the assessment analysed. Adolescent's gender, self-reported satisfaction with life, and the experience of involvement in an accident in agriculture occurred to be the strongest predictors of the assessment of hazards. According to the above-presented considerations, boys who had been involved in an accident at work, and those less satisfied with life, evaluated risk related with work in agriculture as higher. Also, the evaluation of risk was higher 
the larger the amount of time devoted by the adolescent to work, and the worse material standard of the adolescent's family. All these variables together explain the relatively high percentage of variance of the assessment of risk related with work in agriculture (24\%). Other relatively important factors explaining the assessment of risk related with work in agriculture were: worse material standard of the family and engagement of the adolescent in work for a longer time. This result seems to confirm the role of a difficult material situation of the family, or even poverty, in inappropriate engagement of children in work, including dangerous jobs, which was also mentioned by other researchers. Assessment of the risk related with work was also higher in the case of adolescents who were less satisfied with life, which may suggest that their life conditions were more difficult, and many important developmental needs were not satisfied. Boys were more exposed to the performance of dangerous jobs on a family farm than girls. It may be presumed that this was due to the fact that these jobs often required more physical strength and resistance to fatigue, which more often characterized the boys than the girls. Involvement in an accident made adolescents aware to the perception of this risk. This seems to indicate that the provision of sufficient knowledge, for example, of training courses and prophylactic programmes may increase awareness of hazards, and facilitate their realistic assessment, and consequently undertaking prevention and protection actions.

From among four groups of factors considered in the regression analysis, variables belonging to three groups (characteristics of the family, adolescent, and work performed by the adolescent) were important for the explanation of the assessment by adolescents of risk at work on parents' farm. In turn, no relationship was observed between assessment of risk and motivation by which adolescents were guided while undertaking work on parents' farm. This motivation varied, although work was most frequently undertaken, by both boys and girls, due to the belief that this was their duty, and also for the reason that in this way they wished to learn how to perform this work. In the case of girls, the fact of being asked to perform such work was important, whereas for boys, they liked this work. However, motivation for undertaking work was not important for assessing work-related risk.

\section{CONCLUSIONS}

Child work still remains an important problem sparking international debates, and it is commonly considered that child work occurs in poorly developed countries. Due to such an attitude, this phenomenon may remain unrecognized in the developed countries, including European countries. Therefore, it is extremely important to investigate this problem in these countries in order to determine its scale and associated threats. Child work is most common in agriculture, especially on family farms. In this sector of the economy, children are engaged in work from a relatively young age, and this work is considered as one of the

The current study conducted in a representative group of adolescents aged 14-15, thus below the age which enables employment, demonstrated that the vast majority of respondents were engaged in various jobs on their parents' farm. Their work was performed within varied working times which differed with respect to the seasonal character of work in agriculture. Thus, the phenomenon of work is considerably common in this age group.

While considering child work, two main trends may be distinguished [19]. Within the dominant trend, only threats related with work are indicated, whereas within the second trend, it is also appreciate the benefits which it brings for the children. Thus, according to the second approach, it is important to undertake actions resulting in the elimination, or at least a decrease, in the potential work-related hazards for children, while maintaining the possible benefits from this work. An important aspect of minimizing the potential workrelated risk is awareness of these hazards, and compliance with the rules of work safety.

The study also indicates the necessity to increase awareness of the hazards related with work on a farm, mainly because the majority of adolescents do not perceive such risk, and it may be presumed that they do not undertake appropriate protective measures against possible harm. Adolescents coming from families where the economic situation is worse, who devote a greater amount of time to work and perform heavier work, are exposed to higher risk, are less satisfied with life, and had been involved in an accident in the past. Boys experienced these hazards to a greater degree than girls. Therefore, although preventive actions should be undertaken with respect to all working children, this group of adolescents is exposed to hazards to the greatest degree. Apart from actions undertaken to eliminate the potential harm related with child work, actions are important to enhancing the benefits for children resulting from their work. These benefits may include an improvement of the material standard, good relations with family members, acquisition of knowledge which favours transition to the labour market, development of interests, responsibility, and belief in self-efficacy and self-esteem.

\section{Acknowledgements}

The study was financed by the National Science Centre, Kraków, Poland (Project No. UMO-2014/15/B/HS6/03534).

\section{REFERENCES}

1. Kohn JG, Pollock JC. Comparing coverage of child labour and national characteristics: a cross-national exploration. Atlantic Journal of Communication. 2014; 22: 211-228.

2. The End of child Labour: Within Reach. Global Report under the followup to the ILO Declaration on Fundamental Principles and Rights AT Work. ILO. Geneva, 2006.

3. Diallo Y, Etienne A, Mehran F, Global child labour trends 2008-2012. ILO. Geneva 2013.

4. Global Estimates of Child Labour. Results and trends, 2012-2016. ILO. Geneva, 2017.

5. Admassie A. Child labor and schooling In the context of a subsistence rural economy: can they be compatible? Int J Educ Dev. 2003; 23: 167-185.

6. Cigno A, Rosati FC, Guarcello L. Does Globalization Increase Child Labor? World Dev. 2002; 130: 1579-1589.

7. Gumus SG, Wingenbach G. The Child Labor Problem in Turkish Agriculture: What Can We Do? Soc Indic Res. 2016; 3: 1193-1215.

8. Kodeks Pracy Dz. U. 1974 Nr 24 poz. 141.

9. Ustawy z dnia 7 września 1991 r. o systemie oświaty. Dz. U. z 2004 r. Nr 256, poz. 2572 (teks jednolity z późn. zm).

10. Diallo Y, Etienne A, Mehran F. Global child labour trends 2008-2012. ILO. Geneva, 2013.

11. Fors HC. Child labour: A review of recent theory and evidence with policy implications. J Econ Surv. 2010; 26 (4): 570-593.

12. Webbink E, Smits J, De Jong E. Hidden Child Labor: Determinants of Housework and Family Business Work of Children in 16 Developing Countries. World Dev. 2012; 40(3): 631-642. 
13. Wypadki przy pracy i choroby zawodowe rolników oraz działania prewencyjne KRUS w 2003 roku. KRUS, Warszawa, 2004.

14. Wypadki przy pracy i choroby zawodowe rolników oraz działania prewencyjne KRUS w 1999 roku. KRUS. Warszawa 2000.

15. Lachowski S, Zagórski J, Obciążenie praca dzieci z rodzin rolniczych. Zmiany w ostatnim dziesięcioleciu. IMW, Lublin, 2010.

16. Lachowski S, Zagórski J. Child labour for the benefit of the family in rural Poland. Ann Agric Environ Med. 2011; 18(2): 25-31.

17. Florek M, Lachowski S, Sosnowska S. Zagrożenia związane $z$ wykonywaniem przez dzieci prac rolnych w opinii uczniów szkół wiejskich województwa kujawsko-pomorskiego. Wieś i Rolnictwo. 2010; 1: 48-58.

18. Lachowski S. Praca dzieci w rodzinach wiejskich Lubelszczyzny. IMW, Lublin, 2013.

19. Aufseeser D, Bourdillon M, Carothers R, Lecoufle O. Children's work and children's well- being: Implications for policy. Development Policy Review. 2018; 36: 241-261.

20. Lachowski S. Znaczenie pracy dzieci dla funkcjonowania rodziny rolniczej. In: Jabłoński A, Szyszka M, Gizicka D, editors. Współczesna rodzina polska. Przemiany, zagrożenia, wyzwania. Lublin: KUL; 2014 p. 115-127.

21. Bourdillon M. Levison D. Myers W. \& White B. Rights and Wrongs of Children's Work. Rutgers University Press. Retrieved July. 2010. from www.jstor.org/stable/j.ctt5hj7n8

22. Contribution des enfants au travail de la terre et á sa preservation: Les liens entre l'agriculture et les droits de l'enfant Agence canadienne de dèveloppement international. Canada 2006.
23. Sobieraj W. Socjalizacja ekonomiczna dzieci jako czynnik rozwoju kapitału ludzkiego. Nauki Społeczne/Social Sciences 2013; 2(8): 183193.

24. Al.-Gamal E, Hamdan-Mansour AM, Matrouk R, Al-Nawaiseh M. The psychosocial impact of child labour in Jordan: A national study. Int J Psychol. 2013; 48(6): 1156-1164.

25. Roggero P, Mangiaterra V, Bustreo F, Rosati F. The Health Impact of Child Labor in Developing Countries: Evidence From Cross-Country Data. Am J Public Health. 2007; 97(2): 271-275. Available from: https:// www.researchgate.net/publication/6605674

26. Gamlin J, Camacho AZ, Ong M, Hesketh T. Is domestic work a worst form of child labour? The findings of a six-country study of the psychosocial effects of child domestic work. Children's Geographies. 2015; 13: 2, 212-225. https://www.tandfonline.com/doi/full/10.1080/1 4733285.2013.829660

27. Lachowski S, Lachowska B. Effect of paid work on health in opinions of Polish adolescents aged. Agric Environ Med. 2018; 25(4): 672-679.

28. Egan S. Tackling the rise of Child labour in Europe: homework for the European court of human rights. International and Comparative Law Quarterly. 2015; 64: 601-630.

29. Muižnieks N. Commissioner for Human Rights of the Council of Europe. Report 2013. https://rm.coe.int/16806db749

30. Lachowski S, Lachowska B. Aktywność ekonomiczna młodzieży w Polsce. Lublin: UMCS; 2018.

31. Global Estimates of Child Labour. Results and trends, 2012-2016. ILO, Geneva, 2017. 